Ks. Jerzy DUDA*

\title{
PRAWO WIARY CZY UCZYNKI PRAWA? DYLEMAT PIERWSZYCH CHRZEŚCIJAN W COMMENTARIUM IN EPISTULAM AD ROMANOS ORYGENESA
}

Jednym z istotnych problemów, które podzieliły rodzący się Kościół, był spór, jaki rozgorzał wewnątrz wspólnoty wierzących między judaizującymi a chrześcijanami pochodzącymi z pogaństwa, dotyczący w głównej mierze kwestii zachowania przepisów Starego Prawa oraz związanego z nim obrzezania. Grupa ortodoksyjnych judeochrześcijan, głównie z Jerozolimy, będących pod znacznym wpływem nawróconych faryzeuszów, wciąż przywiązanych do form życia żydowskiego oraz zdominowanych przez Jakuba i jego idee, żądała od przychodzących do Kościoła pogan przyjęcia Prawa Mojżeszowego oraz postępowania zgodnie $\mathrm{z}$ nim, co było równoznaczne $\mathrm{z}$ utrzymaniem przepisów dotyczących obrzezania ${ }^{1}$. Pierwotna kontrowersja zażegnana na tzw. „soborze Jerozolimskim” przybrała na sile w III w. w nieco innej formie i wymagała ponownego omówienia oraz zinterpretowania $w$ duchu całościowej doktryny chrześcijańskiej. Było to związane z jednej strony z żywymi ciagle poglądami judaizujących, $\mathrm{z}$ drugiej zaś $\mathrm{z}$ rozpowszechnionym $\mathrm{w}$ tym czasie zjawiskiem gnozy.

Gnostycy mimo wielu rozbieżności w poszczególnych odgałęzieniach zgodni byli w tzw. „odświatowieniu” ziemskich relacji, a skoncentrowaniu się na rzeczywistości ducha ${ }^{2}$. W praktyce prowadziło to do deprecjonowania świata materialnego, jego struktur, instytucji, jak również braku zainteresowania pozytywnym kształtowaniem współżycia społecznego przez przestrzeganie odpowiedniego systemu etycznego. Przyjęcie w założeniach systemowych prawdy o pochodzeniu świata materialnego od demiurga, który zniewolił człowieka, prowadziło w konsekwencji do krytyki oraz zanegowania przez

* Ks. dr Jerzy Duda - wykładowca patrologii w Wyższym Seminarium Duchownym im. Jana Pawła II w Siedlcach; e-mail: jerzy.duda@onet.eu.

${ }^{1}$ Por. J. Daniélou, Teologia judeochrześcijańska, tłum. S. Basista, Kraków 2002, 20-21; H. Chadwick, Kościót w epoce wczesnego chrześcijaństwa, thum. A. Wypustek, Warszawa 2004, 10-13; K.H. Schelkle, Teologia Nowego Testamentu, t. 3: Etos, thum. M.L. Dylewski, Kraków 1984, 75-77; J. Gnilka, Pierwsi chrześcijanie. Źródła i początki Kościoła, tłum. W. Szymona, Kraków 2004, 328-341.

${ }^{2}$ Por. K. Rudolph, Gnoza, tłum. G. Sowiński, Kraków 2003, 262-265. 
gnostyków jego praw. Stąd Stary Testament, z jego przykazaniami i prawami mówiącymi człowiekowi, co mu wolno a czego nie, postrzegany był w tym środowisku jako wyraz „kosmicznego” uciemiężenia i zniewolenia ${ }^{3}$. Gnostyk dążył do restytucji świata ducha. Próba budowania ładu społecznego w oparciu o Prawo ${ }^{4}$ i wynikająca z niego etykę rodziło w nim bunt, krytykę, jak również nieprzejednane stanowisko antyżydowskie ${ }^{5}$. Do zbawienia, a więc i wyzwolenia z więzów materii, prowadzi poznanie.

Tego typu dualistyczne tendencje w sposobie postrzegania ziemskiego świata i jego struktur społeczno-politycznych oraz dążenie do skoncentrowania się jedynie na rzeczywistości duchowej, odkrywanej głównie przez wiarę i prowadzącej do poznania Boga, pojawiły się również we wczesnym Kościele. Spowodowane one były między innymi pewnym dysonansem odczuwalnym w samym nauczaniu biblijnym. Z jednej strony przytaczano nauczanie św. Jakuba i jego słynne stwierdzenie, że „wiara bez uczynków jest martwa” (Jk 2, 26), z drugiej zaś słowa Pawłowe wskazujące, że uczynki Starego Prawa (włącznie z przepisami dotyczącymi obrzezania), utraciły swoją aktualność soteriologiczną zaś usprawiedliwienie pochodzi z wiary (por. Rz 3, 21-31; Ga 2, 15 - 3, 20). Kwestia ta znalazła swoje dogłębne i wieloaspektowe opracowanie w nauczaniu jednego z najwybitniejszych pisarzy wczesnochrześcijańskich i egzegetów Kościoła, jakim był Orygenes († ok. 253). Przeprowadzona kwerenda wykazała, iż zwroty „prawo wiary” i „Prawo uczynków” pochodzące z Listu św. Pawła do Rzymian $(3,27)$ zostały wykorzystane przez Adamantiosa jako terminy techniczne, zaś najpełniejsze ich wyjaśnienie znalazło się w komentarzu do tej księgi. W związu z tym Commentarium in Epistulam ad Romanos stał się dla mnie głównym źródłem badawczym. Pomocnym w sprecyzowaniu terminologii, jak też w przedstawieniu tematyki „epinoi” Chrystusa był także Commentarium in Evangelium Joannis, jak również traktat Contra Celsum.

Celem zasadniczym niniejszego opracowania jest analiza tekstów egzegetycznych Orygenesa dotyczących relacji między wiarą i uczynkami, jak również przedstawienie kontrowersji z tym związanych. By przystąpić do tego zadania konieczne jest wyjaśnienie terminów: „prawo wiary” i „Prawo uczynków", nie tylko na poziomie semantyczno-teologicznym, ale również w duchu całościowej doktryny Scholarchy z Aleksandrii. Mamy nadzieję, że ta praca pozwoli lepiej zrozumieć postępujący w środowisku wczesnego Kościoła proces samoświadomości doktrynalnej i tym samym uniezależnienia od judaizmu czy wpływów heterodoksyjnych.

\footnotetext{
${ }^{3}$ Por. H. Jonas, Religia gnozy, thum. M. Klimowicz, Liszki 1994, 62.

${ }^{4} \mathrm{~W}$ niniejszym artykule używając terminu „Prawo” zasadniczo mamy na uwadze Prawo Mojżeszowe zawarte w Starym Testamencie. Wyjątkiem będzie posługiwanie się tym terminem w celu omówienia tematyki „epinoi” Syna Bożego. W innym wypadku jest wykorzystywany termin „prawo” pisany małą literą. Forma taka została również przyjęta przez tłumacza dzieł Orygenesa - S. Kalinkowskiego.

${ }^{5}$ Por. Rudolph, Gnoza, s. 262.
} 
Interesującą kwestią, która już na początku narzuca się przy szczegółowej analizie zachowanych do dnia dzisiejszego dzieł Adamantiosa, jest myśl, iż próbował on zniwelować, już na poziomie semantyki, napięcie między potrzebą wiary i koniecznością postępowania zgodnie z przyjętymi zasadami prawa. Bardzo często omawiając zagadnienie wzajemnych relacji między wiarą i uczynkami mówił, iż jedno i drugie pojęcie jest związane z rzeczywistością prawa. Istnieją bowiem uczynki Prawa (lex operum), ale również prawo wiary (lex fidei) ${ }^{6}$.

Ten oryginalny sposób powiązania, a nie przeciwstawienia, był możliwy dzięki stosowanej przez Orygenesa alegorycznej metodzie interpretacji Pisma Świętego ${ }^{7}$. W tym kluczu termin Prawo (lex) i związane z nim uczynki Prawa (lex operum) będą nie tylko, w sensie literalnym, oznaczać zawarte w Starym Testamencie przepisy Prawa Mojżeszowego (lex Moysi), lecz nabiora głębszego i wieloaspektowego znaczenia. Orygenes omawiając ich wartość semantyczną sięgnie do skarbca biblijnego i zestawiając obok siebie poszczególne teksty pokaże ich bogactwo. Nawiąże przy tym do nauczania Apostoła Narodów, który w Liście do Rzymian

„przedstawia różne prawa, w jednym miejscu mówi o Prawie Mojżesza, gdzie indziej o prawie wiary, na przykład: «Gdzież więc jest podstawa do chlubienia się? Została uchylona. Przez jakie prawo? Czy przez prawo uczynków? Nie, przez prawo wiary» $(\mathrm{Rz} 3,27)$. Ukazuje oprócz tego i inne prawa, o których mówi: «Albowiem wewnętrzny człowiek we mnie ma upodobanie zgodnie z Prawem Bożym» (Rz 7, 22)"».

Analizując w tym miejscu powyższy fragment postaramy się omówić wartość semantyczną terminologii oraz problematykę związaną z uczynkami Prawa.

1. Uczynki Prawa. Orygenes wykorzystał nauczanie Apostoła Pawła, by pokazać, iż błędem jest jednoznaczne wiązanie terminu „prawo” z Prawem Mojżeszowym. Zarówno bowiem prawo wiary, jak też Prawo Mojżeszowe są nierozerwalnie związane z Prawem Bożym, którym winien się kierować człowiek dążący do osiągnięcia zbawienia. W dalszej części cytowanego tekstu Adamantios przeciwstawia się nauce marcjonitów, którzy odrzucili Stary Testament oraz zawarte $\mathrm{w}$ nim przepisy, wiążąc jego pochodzenie $\mathrm{z}$ uzurpatorem, jakim według ich przekonania jest demiurg. Na potwierdzenie zasadności swojej nauki przywoływali oni słowa św. Pawła (jakoby wroga judaizmu),

\footnotetext{
${ }^{6}$ Por. Origenes, Commentarium in Epistulam ad Romanos IV 1, PG 14, 959: „Cum superius duas proposuerit leges, quarum unam operum, aliam fidei nominavit, per quam legem fidei excludi gloriationem dicit eorum qui in legis operibus gloriantur; et pronuntiaverit fide justificari hominem sine operibus legis".

${ }^{7}$ Por. M. Simonetti, Między dostownościq a alegoriq, tłum. T. Skibiński, Kraków 2000, 71-98.

${ }^{8}$ Origenes, Commentarium in Epistulam ad Romanos IV 4, PG 14, 972, thum. S. Kalinkowski: Orygenes, Komentarz do Listu św. Pawła do Rzymian, PSP 57, Warszawa 1994, 206.
} 
mówiące, iż Prawo „pociąga za sobą gniew” (Rz 4, 14-15). W związki z tym uczynki tak rozumianego Prawa nie tylko już nie obowiązują, lecz należy je odrzucić jako wrogie prawdzie objawionej przez Chrystusa. W odpowiedzi na to Orygenes dowodzi, iż nie należy tekstu Pawłowego interpretować dosłownie, gdyż prowadzi to do wypaczenia jego sensu. Gniew Boży oraz odrzucenie rodzi się nie dlatego, iż Żydzi przyjęli w życiu zasady Prawa Mojżeszowego, nadane przez „niedoskonałego boga”, lecz z przestępstwa, które jest związane $\mathrm{z}$ grzechem. Prawo grzechu toczy bowiem w człowieku walkę z Prawem Bożym i jest starsze niż Prawo nadane przez Mojżesza i proroków. Świadczy o tym deprawacja i zło ludzi żyjących w najdawniejszych czasach, a opisane chociażby w Księdze Rodzaju (grzech pierwszych ludzi, zbrodnia Kaina, nieprawości mieszkańców Sodomy) ${ }^{9}$. Błędne są zatem poglądy tych wszystkich, którzy na własny użytek dowolnie komentując jedynie wybrane perykopy, wypaczają naukę Bożą i rozrywają jedność Bożego objawienia. Do takich z pewnością należy Marcjon,

„który twierdzi, że Bóg Prawa jest różny od Ojca Chrystusa, przez wiarę swoją nie ustanawia Prawa ani go nie potwierdza, lecz usuwa Prawo. Tak samo czynią ebionici; tak samo robią ci wszyscy, którzy w wiarę katolicką wszczepiają jakieś zepsucie. Ja stosownie dodam i to jeszcze, że każdy, kto wierząc w Chrystusa czyni dobrze i trzyma się z dala od wszelkiej plamy grzechu, starannie potwierdza Prawo" ${ }^{10}$.

Scholarcha z Aleksandrii jednoznacznie ukazuje nie tylko integralność Starego i Nowego Testamentu oraz objawionej w nich prawdy o Jednym Bogu, lecz również powiązanie ze sobą rzeczywistości wiary oraz prawa uczynków przez Jezusa Chrystusa ${ }^{11}$. Tym samym prowadzi do odkrycia fundamentalnego znaczenia homonimu, jakim jest termin ,prawo”. Jedną z podstawowych zasad stosowanych przez Orygenesa w komentowaniu tekstów Pisma Świętego jest chrystocentryzm. Widzimy ją zastosowaną również i w tym przypadku. W sensie ścisłym bowiem termin „prawo” jest niczym innym jak „epinoią" Syna Bożego ${ }^{12}$. Zatem podobnie jak nie może być różnicy między Bogiem Prawa a Ojcem Chrystusa, tak również nie może być przeciwstawienia miedzy wiarą a uczynkami, gdyż zarówno wiara, jak i postępowanie zgodne z Prawem, prowadzą ostatecznie do Tego, przez którego dokonuje się dzieło usprawiedliwienia oraz zbawienia. W Komentarzu do Listu św. Pawła do Rzymian mówi o tym Adamantios w sposób następujący:

\footnotetext{
${ }^{9}$ Por. tamże.

${ }^{10}$ Tamże III 1, PG 14, 957, PSP 57, 186-187.

${ }^{11}$ Por. tamże.

${ }^{12}$ Por. tenże, Commentarium in Evangelium Joannis I, IX 52-53, ed. C. Blanc, SCh 120, Paris 1966, 88. Szczegółowa koncepcja tytułów chrystologicznych w nauczaniu Orygenesa w kontekście „epinoi” Mądrości została omówiona w: M. Szram, Chrystus - Mądrość Boża według Orygenesa, Lublin 1997, 63-84.
} 
„Chrystus nie podlega Prawu, lecz jest pełnią Prawa: i jak jest Sprawiedliwością, dzięki której wszyscy stają się sprawiedliwi, jak jest Prawdą, dzięki której wszyscy trwają w prawdzie, [...] tak samo jest Prawem, dzięki któremu wszyscy podlegają Prawu. Przychodzi więc na sąd nie jako ten, który podlega Prawu, lecz jako ten, który sam jest Prawem"13.

Tekst ten świadczy, iż według Orygenesa termin „Prawo” jest niczym innym, jak kolejnym imieniem (,epinoią") Chrystusa. On bowiem mając boską jedność, dzięki Ojcu stał się zbiorem dóbr (określeń, imion) dla ludzi ${ }^{14}$. Dzięki temu człowiek może przechodzić od jednego daru do drugiego, wzrastając przez to w doskonałości oraz stając się coraz bardziej poddany Bogu. Dlatego Jezus odkrywa się przed człowiekiem jako Mądrość, Brama, Droga oraz Prawo i wzywa do pełnienia uczynków zgodnych w wolą Boga ${ }^{15}$. Zatem podobnie jak wiara prowadzi do usprawiedliwienia w Chrystusie Jezusie, tak również uczynki Prawa, a więc życie na obraz Chrystusa, prowadzą ostatecznie do doskonałości i zjednoczenia z Panem w jednym duchu ${ }^{16}$.

Zgodnie z nauczaniem Adamantiosa termin „Prawo”, oprócz fundamentalnego znaczenia, tożsamego z osobą Syna Bożego, występuje zarówno w Starym, jak i Nowym Testamencie, w dwóch innych podstawowych rozumieniach ${ }^{17}$. Doprecyzowanie tych znaczeń oraz systematyka jest konieczna do właściwej analizy, która ostatecznie ujawnia progres semantyczny terminu oraz ukazuje ukierunkowanie ku znaczeniu chrystologicznemu. Orygenes bowiem uważał, iż istnieje również historiozbawczy proces w odkrywaniu prawdy objawionej oraz treści, które ukryte jak w „obrazie” i ,figurze” w nauczaniu Prawa i pismach prorockich w Starym Testamencie, dzięki wcieleniu Chrystusa ujawniły swoją tajemnicę i dopiero w Nim stały się właściwą Ewangelią ${ }^{18}$. Stąd człowiek, który podlega prawdziwemu Prawu, przyjmuje w pełni Ewangelię, zaś ten kto wierzy Ewangelii, zachowuje Prawo i postępuje zgodnie z nim ${ }^{19}$. Mając to na uwadze odnajdujemy w Biblii termin ,prawo" jako literalne określenie Prawa Mojżeszowego, obowiązującego w określonym czasie historii zbawienia tych wszystkich, którzy na mocy obrzezania należeli do narodu żydowskiego oraz byli zobowiązani do postępowania zgodnie z jego nakazem ${ }^{20}$.

\footnotetext{
${ }^{13}$ Origenes, Commentarium in Epistulam ad Romanos III 6, PG 14, 939, PSP 57, 164.

${ }^{14}$ Por. tenże, Commentarium in Evangelium Joannis I X 62, SCh 120, 92.

${ }^{15}$ Por. H. Pietras, Wprowadzenie, w: Orygenes, Komentarz do Ewangelii wedlug św. Jana, ŹMT 17, Kraków 2000, 12-13.

${ }^{16}$ Por. Origenes, Commentarium in Epistulam ad Romanos III 6, PG 14, 939.

${ }^{17}$ Chodzi w tym przypadku głównie o nauczanie św. Pawła i podkreślaną przez Orygenesa kwestię wieloznaczności terminu „Prawo” oraz braku konsekwencji w jego stosowaniu.

${ }^{18}$ Por. Origenes, Commentarium in Evangelium Joannis I, VI 32-36, SCh 120, 76-78.

${ }^{19}$ Por. tenże, Commentarium in Epistulam ad Romanos I 15, PG 14, 861.

${ }^{20}$ Por. tamże III 6, PG 14, 936-937.
} 
W innym znaczeniu ,prawo” oznaczało „zaszczepioną w duszy” i „wyrytą w sercu zasadę", która nakazuje, co należy czynić, a czego się wystrzegaćéc. Orygenes ma tutaj na uwadze prawo naturalne. Ani Żydzi, ani poganie nie są od niego wolni. Prawo naturalne, podobnie jak Prawo Mojżeszowe, zostało dane przez Boga, by pomóc ludziom rozwijać się w mądrości oraz cnocie, a przez to dokonywać w życiu właściwych dobrych wyborów ${ }^{22}$. Scholarcha z Aleksandrii uważa, iż prawu naturalnemu podlega nie tylko człowiek, lecz również aniołowie oraz wszystkie stworzenia rozumne ${ }^{23}$. Uczynki wypływające zarówno z Prawa Mojżeszowego, jak również z prawa naturalnego, nie dadzą jednak usprawiedliwienia, które prowadzi do zbawienia. Prawo bowiem określa jedynie granice wolności. Jest niczym innym, jak darem Bożym, dzięki któremu człowiek uczy się, co należy czynić a czego unikać, co jest dobrem a co przestępstwem. Prawo pozwala odkryć właściwą drogę w życiu i chroni przed występkiem. Błędem są poglądy heretyków, którzy uważaja, że przez ustanowienie w raju zakazu (prawa) spożywania owocu z drzewa poznania dobra i zła narodził się grzech ${ }^{24}$. Grzech narodził się nie z prawa, lecz dzięki prawu mógł być poznany. Podobnie jak w medycynie przez odpowiednią diagnozę poznaje się rodzaj schorzenia, tak również dzięki prawu ustanowionemu przez Boga można odkryć naturę zła i grzechu. Sztuka lekarska nie jest więc przyczyną choroby, lecz dobrem, które pomaga uniknąć lub zwalczyć dolegliwość. Podobne zadanie pełni prawo. Przekazuje ono naukę, chroni wartości oraz wskazuje właściwy sposób postępowania ${ }^{25}$. Jednakże samo zachowywanie prawa, czy to starotestamentalnego, czy też naturalnego, oraz pełnienie uczynków, które ono nakazuje, nie jest związane z zasługą. Prawo bowiem służy jedynie słabym i grzesznym ${ }^{26}$. Pozwala na uniknięcie kary ${ }^{27}$. Nie wprowadza jednak w rzeczywistą bliskość z Bogiem, jaką jest przyjaźń i dziedzictwo. Ci, którzy dbają tylko o literalne zachowanie sprawiedliwości wynikające z uczynków prawa, nie unikną sądu Bożego. Nie znaczy to, iż będą potępieni. Prawo bowiem prowadzi do poddania całego świata Bogu ${ }^{28}$. Nawet jeśli człowiek nie ma wiary, a pełni dobre uczynki, otrzyma nagrodę, jednak nie będzie ona pełna ${ }^{29}$. Postawę tych, którzy pełnią jedynie uczynki Prawa można porównać do sylwetki faryzeusza, który w przypowieści ewangelicznej przyszedł do świątyni i dziękował Bogu za to, że nie jest jak inni źli ludzie, że zachowuje posty i inne przepisy wskazane przez Prawo. Nie odszedł on usprawiedliwiony, mimo, iż - być może

\footnotetext{
${ }^{21}$ Pogląd, że prawo jest wpisane w naturę człowieka był głoszony również przez stoików, por. G. Reale, Historia filozofii starożytnej, tłum. E.I. Zieliński, III, Lublin 1999, 424-426.

${ }^{22}$ Por. Origenes, Commentarium in Epistulam ad Romanos III 6, PG 14, 937-939.

${ }^{23}$ Por. tamże III 6, PG 14, 938-940.

${ }^{24}$ Por. tamże, PG, 14, 940-941.

${ }^{25}$ Por. tamże.

${ }^{26}$ Por. tamże IV 4, PG 14, 973.

${ }^{27}$ Por. tamże, PG 14, 971-972.

${ }^{28}$ Por. tamże III 6, PG 14, 939.

${ }^{29}$ Por. tamże II 7, PG 14, 889.
} 
- modlił się prawdziwie. Przyczyną jego duchowej choroby była chełpliwość wyrosła na Prawie uczynków. Zatem literalne zachowywanie prawa zarówno naturalnego, jak też Mojżeszowego, nie daje usprawiedliwienia przez Bogiem. Usprawiedliwienie rodzi się bowiem z pokory, która jest prostą drogą wiodącą do wiary. Chełpliwość judaizmu, dumnego ze swych uczynków Prawa - naucza Orygenes - została napiętnowana i usunięta przez pokorę krzyża Jezusa Chrystusa oraz prawo wiary ${ }^{30}$.

2. Prawo wiary. Rzeczywistość wiary opisana na kartach dzieł Adamantiosa jest niezwykle bogata. Dotyczy ona z jednej strony sfery najbardziej ukrytej i intymnej, jaką jest serce człowieka, z drugiej zaś ma swoje odwzorowanie we wszystkich przejawach życia ludzkiego ${ }^{31}$. Nie jest dziełem człowieka, choć przez ludzi jest głoszona i wyznawana. Wiara pochodzi od Boga. Jest darem Jego bezgranicznej miłości oraz łaski Ducha Świętego ${ }^{32}$. Staje się dla człowieka fundamentem usprawiedliwienia. Orygenes przeciwstawiając się zarzutom pogańskiego filozofa Celsusa zarzucającego chrześcijanom prymitywizm i naiwność ich wierzeń nauczał, iż wiara: ,jest przyczyną naszego przywiązania do Chrystusa" 33 . Tłumacząc zaś jej znaczenie mówił, iż jest ona godna pochwały, gdyż przez nią:

„poddajemy się Bogu wszechrzeczy dziękując Temu, który doprowadził nas do tej wiary, i wyznając, że nie mógł tego dokonać bez pomocy Bożej”34.

Wiara jest jedyną droga, która wiedzie do życia wiecznego. Choć jest rzeczywistością dynamiczną, to jednak taką samą dla wszystkich istot stworzonych. Wiara, która była głoszona i przyjęta przez Rzymian, jest identyczną z tą, która jako Dobra Nowina dociera do wszystkich krańców ziemi. Adamantios uważa, że jest ona przekazywana nie tylko na całym świecie, lecz także w niebie. Przez Chrystusa oraz Jego zbawczą ofiarę dokonuje się dzieło pojednania całego stworzenia i poddania go Bogu Ojcu ${ }^{35}$. Wiara bowiem jest niczym innym jak uznaniem Boga, który zbawia, i poddaniem się w pokorze Jego woli. Dar ten można przyrównać do korzenia tkwiącego dzięki łasce Bożej w glebie duszy ludzkiej. Gdy dotknie go - jak deszcz życiodajny - błogosławieństwo usprawiedliwienia, wystrzeli ku niebu rozkwitłymi gałęziami pełnymi owoców dobrych uczynków ${ }^{36}$. Bóg w swojej bezgranicznej miłości, z mocą większą niż moce niebieskie, pochyla się ku człowiekowi, by obdarzyć go łaską prawdziwej mądrości. Dokonuje się to na drodze wiary. Jest ona potrzebna do tego, by

\footnotetext{
${ }^{30}$ Por. tamże III 9, PG 14, 954.

${ }^{31}$ Por. tamże IV 1, PG 14, 960.

${ }^{32}$ Por. tamże IV 5, PG 14, 974.

${ }^{33}$ Por. tenże, Contra Celsum III 39, ed. M. Borret, SCh 136, Paris 1968, 92.

${ }^{34}$ Tamże, tłum. S. Kalinkowski: Orygenes, Przeciw Celsusowi, Warszawa 1986, 161.

${ }^{35}$ Por. tenże, Commentarium in Epistulam ad Romanos I 9, PG 14, 855.

${ }^{36}$ Por. tamże IV 1, PG 14, 965.
} 
człowiek mógł odkryć tajemnicę, która została zakryta dla dawnych wieków, a teraz dzięki nauce Prawa i proroków, w świetle dzieła odkupienia dokonanego przez Jezusa Chrystusa, została ujawniona. Zostaliśmy doprowadzeni do wiary po to, byśmy mogli spełnić swoje życiowe powołanie, a więc oddawać chwałę prawdziwemu Bogu, Stwórcy wszystkich rzeczy. Wiara prowadzi do mądrości, dzięki której możemy wznosić się na poziom obcowania z rzeczywistością doskonałości Bożej. Nie jest aktem czysto intelektualnym, gdyż wyraża się przez prawo uczynków. Niemniej jednak jest związana z darem poznania, który podobnie jak wiara oraz mądrość jest łaską Ducha. Poznanie, według Scholarchy z Aleksandrii, rodzi się na fundamencie wiary i prowadzi do jej udoskonalenia ${ }^{37}$. W stwierdzeniu takim widzimy wyraźną opozycję do nauki gnostyków, według których to poznanie ma priorytetowe znaczenie w dotarciu do prawdy. Orygenes nie deprecjonuje poznania, uważa bowiem, że dzięki łasce Bożej wiara staje się poznaniem ${ }^{38}$. Można więc wyszczególnić pewną gradację w procesie kroczenia ku Boga. Początek i fundament stanowi wiara ${ }^{39}$. Na niej zasadzone jest poznanie, które prowadzi ostatecznie do Mądrości ${ }^{40}$.

Wiara ma charakter dynamiczny. Istnieją bowiem ludzie, którzy posiadają małą cząstkę wiary, inni większą, a są również tacy, którzy mają „całą wiarę (omnem fidem)" "41. Wynika stąd, że istnieje proces wzrostu i rozwoju w wierze. U jego szczytu znajduje się wiara doskonała, którą można nazwać szczęśli$w_{a}^{42}$. Adamantios charakteryzuje ją w sposób następujący:

„Zdrową wiarą natomiast nazywa się wiarę doskonałą, taką, której niczego nie brakuje. To ona jest zdania, że można jeść wszystko, to znaczy, że wszystko można pojąć. Kto ma taką wiarę, ten zwie się człowiekiem duchowym i rozsądza wszystko, i nie mogą zgorszyć go żadne słowa" ${ }^{43}$.

Wiara zatem doskonała jest związana $\mathrm{z}$ doskonałym poznaniem. Prowadzi ona do szczególnej bliskości z Bogiem i dziedzictwa życia wiecznego. Wyraża się również w przyjęciu tajemnicy i wyznawaniu Trójjedynego Boga: Ojca, Syna i Ducha Świętego ${ }^{44}$. Taka wiara ma moc usprawiedliwienia nawet wielkiego grzesznika ${ }^{45}$. Nie ma nic niemożliwego dla tego, kto posiada taka właśnie wiarę. Gdy współdziała z mocą Bożą może góry przenosić oraz czynić cuda $^{46}$. Dlatego też apostołowie prosili Chrystusa, by pomnożył ich wiarę ${ }^{47}$.

\footnotetext{
${ }^{37}$ Por. H. Crouzel, Orygenes, tłum. J. Margański, Bydgoszcz 1996, 153.

${ }^{38}$ Por. Origenes, Commentarium in Epistulam ad Romanos VIII 1, PG 14, 1159-1160.

${ }^{39}$ Por. tamże IV 6, PG 14, 981.

${ }^{40}$ Por. Crouzel, Orygenes, s. 153.

${ }^{41}$ Por. Origenes, Commentarium in Epistulam ad Romanos IV 6, PG 14, 981.

${ }^{42}$ Por. tenże, Contra Celsum III 38, SCh 136, 90.

${ }^{43}$ Tenże, Commentarium in Epistulam ad Romanos IV 6, PG 14, 981, PSP 57, 217.

${ }^{44}$ Por. tamże III 11, PG 14, 957.

${ }^{45}$ Por. tamże IV 1, PG 14, 965.

${ }^{46}$ Por. tenże, Commentarium in Evangelium Matthaei X 19, ed. R. Girod, SCh 162, Paris 1967, 230.

${ }^{47}$ Por. tenże, Commentarium in Epistulam ad Romanos IV 6, PG 14, 981.
} 
Inny charakter posiada wiara prosta. Nie wszyscy bowiem ludzie są w stanie porzucić dotychczasowe swoje życie i całkowicie poświęcić się badaniu proroctw, przypowieści czy też wielu innych symbolicznych wydarzeń, jak również przepisów zawartych w Świętych Księgach. Wielu więc przyjmuje w zaufaniu głoszoną im naukę bez głębszych dociekań oraz filozoficzno-teologicznych spekulacji. Pismo Święte również i taką wiarę pochwala, jeżeli tylko daje ona człowiekowi wsparcie i siłę do wyrwania się z sideł diabelskich oraz bagna grzechu. Wiara pozwala bowiem dojść do nawrócenia, zmiany obyczajów oraz wytrwania w cnocie, nawet jeśli wynika to jedynie z poznanej nauki o karze i nagrodzie, jak też ze strachu przed sprawiedliwym sądem Bożym. Jednakże wiara potrzebuje uzasadnienia i winna być oparta na wiedzy ${ }^{48}$. Wtedy to dzięki pomocy rozumu wzmacnia się jej siła ${ }^{49}$. Człowiek bowiem, który nie ma mocno ugruntowanej wiary w poznaniu, może pod wpływem różnych życiowych burz i nawałnic, osłabnąć w niej, a nawet ją utracićso.

Wiara oparta na wiedzy sprawia, że człowiek zaczyna w życiu kierować się prawem wiary. Zwrot ten został przez Orygenesa zapożyczony z Listu św. Pawła do Rzymian na oznaczenie Prawa Bożego, stanowiącego fundament w postępowaniu człowieka wewnętrznego ${ }^{51}$. Przed przyjściem Chrystusa ludzie otrzymali od Boga w darze prawo naturalne i Prawo Mojżeszowe. Nie były jednak one w stanie przynieść im prawdziwego usprawiedliwienia. Ono bowiem rodzi się jedynie przez wiarę. By lepiej zobrazować tę prawdę Orygenes posłużył się przykładem Abrahama, który dzięki wierze uzyskał usprawiedliwienie i stał się przez to dziedzicem obietnicy oraz przyjacielem Boga ${ }^{52}$. Na czym według Scholarchy z Aleksandrii polegała zasługa Abrahama? Gdyby tylko na wypełnieniu Prawa, to w Piśmie Świętym byłoby napisane, iż Abraham był człowiekiem sprawiedliwym, dobrze postępował, kierował się w życiu zasadami wypływającymi z prawa naturalnego oraz pobożnością i dzięki temu zasłużył na dziedzictwo sprawiedliwości ${ }^{53}$. Tymczasem jednak, „tak jakby prawo to było niewystarczające, otrzymuje rozkaz pójścia za prawem wiary" ${ }^{34}$, które kazało mu opuścić rodzinną ojczyznę i zawierzyć obietnicy. Wiara stała się więc dla niego źródłem usprawiedliwienia i błogosławieństwa. Historia ta wydarzyła się zanim Mojżesz nakazał przestrzeganie przepisów Prawa $^{55}$. Co więcej, zgodnie ze słowami Księgi Rodzaju zasłużył on na usprawiedliwienie zanim przyjął obrzezanie. Zatem to nie jurydyczna przynależność do Narodu Wybranego oraz literalne przestrzeganie przepisów Prawa

${ }^{48}$ Por. tamże VIII 1, PG 14, 1159-1160.

${ }^{49}$ Por. tenże, In Lucam hom. I 3, ed. H. Crouzel - F. Fornier - P. Perichon, SCh 87, Paris 1962, 102-104.

${ }^{50}$ Por. tenże, Commentarium in Epistulam ad Romanos VIII 1, PG 14, 1159.

${ }^{51}$ Por. tamże IV 4, PG 14, 972.

${ }^{52}$ Por. tamże IV 3, PG 14, 970.

${ }^{53}$ Por. tamże IV 4, PG 14, 971.

${ }^{54}$ Tamże, PSP 57, 205.

${ }^{55}$ Por. tamże IV 3, PG 14, 970. 
Mojżeszowego niosą usprawiedliwienie. Otrzymują je ci wszyscy, którzy podobnie jak Abraham kierują się prawem wiary, a przez to stają się dziedzicami Boga i Jego przyjaciółmi ${ }^{56}$. Zgodnie z tym można powiedzieć, iż Abraham jest ojcem wiary nie tylko dla Żydów, lecz także dla pogan. Z tego prawa korzystają również chrześcijanie, gdy kierują się taką samą wiarą.

Błędne jest jednak rozumowanie tych wszystkich, którym się wydaje, iż od momentu przyjścia Chrystusa na ziemię i Jego odkupieńczej ofiary krzyżowej nie obowiązuje wierzącego żadne prawo oraz można lekceważyć dobre uczynki. Dzięki wierze człowiek rzeczywiście dostępuje odpuszczenia wszystkich grzechów, chociażby były największe i najstraszniejsze. Przykładem tego może być łotr, który został ukrzyżowany razem z Chrystusem i prosił Pana, by ten na niego wspomniał, gdy przyjdzie już do swego królestwa ${ }^{57}$. Ewangelia nie wspomina o jego wcześniejszych dobrych uczynkach czy też wierności Prawu Mojżeszowemu. Jezus usprawiedliwił go wyłącznie dzięki jego wyznaniu wiary. Podobnie było z grzeszną kobieta, która w domu faryzeusza drogocennym olejkiem namaściła stopy Chrystusa i obmyła je łzami. Nie z powodu uczynków Prawa, lecz dzięki swojej wierze otrzymała odpuszczenie grzechów ${ }^{58}$. Zatem to wiara jest przyczyną ocalenia. Jednakże człowiek, który został obdarzony usprawiedliwieniem, od tej pory jest zobowiązany do kierowania się w życiu prawem wiary. Bóg udziela odpuszczenia grzechów nie po to, by od nowa pogrążyć się w złu. Przebaczenie dotyczy dawnego życia. Przyjęcie chrztu świętego nie predestynuje jednak automatycznie do uzyskania zbawienia. Kto bowiem będąc już obdarzonym łaską usprawiedliwienia z powrotem upadnie w grzech, podlegać będzie sądowi jako grzesznik ${ }^{59}$. Człowieka dotknięty darem Bożego miłosierdzia winien już od tej pory postępować zgodnie z innym prawem, którego potwierdzeniem będą dobre uczynki. Wiara nie będzie usprawiedliwieniem dla tych, co nie wyzbywają się ,,dawnego człowieka" z jego złym postępowaniem ${ }^{60}$. Możemy przypuszczać, iż odnajdujemy w tych stwierdzeniach aluzje do chrześcijańskiej praktyki przygotowania do przyjęcia chrztu świętego. W VIII księdze Komentarza do Listu św. Pawła do Rzymian Orygenes stwierdza:

„«Wiara bez uczynków jest martwa» (por. Jk 2, 26), i że wiara w Boga nie polega jedynie na słowach, których się uczymy, a które zostały sformułowane lub zapisane przez innych, lecz polega na takim nastawieniu umysłu, jakie okazała owa kobieta, która powiedziała sobie: «Jeżeli dotknę frędzli Jego płaszcza, będę zdrowa» (Mt 9, 21)" ${ }^{\prime 61}$.

\footnotetext{
${ }^{56}$ Por. tamże IV 2, PG 14, 967.

${ }^{57}$ Por. tamże III 9, PG 14, 952-953.

${ }^{58}$ Por. tamże, PG 14, 953.

${ }^{59}$ Por. tamże II 7, PG 14, 889.

${ }^{60}$ Por. tamże IV 7, PG 14, 985-986.

${ }^{61}$ Tamże VIII 1, PG 14, 1159, PSP 57, 414.
} 
Zdrowie duchowe człowieka przejawia się zatem w dobrych uczynkach. One bowiem ujawniają na zewnątrz to, co człowiek nosi w swoim sercu i w kogo wierzy. Uczynki są bowiem ściśle powiązane z wiara. Orygenes wyjaśnia to dokładnie omawiając stwierdzenie św. Pawła o tym, iż Bóg: ,usprawiedliwia obrzezanego dzięki wierze, a nieobrzezanego - przez wiarę" (Rz 3, 30). Usprawiedliwienie „,dzięki wierze” dotyczy Żydów, którzy przyjęli Chrystusa. Wiara stanowiła u nich fundament udoskonalenia postępowania, według zasad Ewangelii. „Przez wiarę” dostępują usprawiedliwienia poganie, którzy zostali powołani do społeczności Kościoła. Początkiem ich drogi są dobre uczynki, a doskonałość osiagają przez wiarę ${ }^{62}$. Wytrwałość w pełnieniu dobra staje się dla nich przyczyną uzyskania nagrody, jaką jest życie wieczne w niebie. Najbardziej jaskrawym tego przykładem są chrześcijańscy męczennicy ${ }^{63}$. Można więc powiedzieć, iż w swoim nauczaniu Orygenes nie deprecjonuje ważności dobrych uczynków. Podobnie jak człowiek sprawiedliwy, który wierzy Bogu i jego słudze Mojżeszowi, od prawdy ukrytej w Starym Testamencie przechodzi do Ewangelii, tak również jego postępowanie oparte na uczynkach Prawa zostaje zastąpione prawem wiary ${ }^{64}$. Ten, kto postępuje sprawiedliwie i wierzy w Chrystusa, potwierdza Prawo ${ }^{65}$. Prawo wiary nie zamyka się w nowych obrzędach czy przepisach rytualnych. Orygenes gani tych, którzy należą formalnie do wspólnoty Kościoła, przychodzą na nabożeństwa, odnoszą się z szacunkiem do hierarchów, składają ofiary, lecz nie przemieniają się wewnętrznie. Według niego nie rozumieją oni, iż wiara winna dążyć do doskonałości i naturalnie przejawiać się w czynach, które są jej prawem: w zachowaniu czystości, pokucie, odrzuceniu występnego życia, doskonaleniu obyczajów i cnót, w miłosierdziu, poszukiwaniu mądrości, a nawet - w skrajnym przypadku - w akcie męczeństwa ${ }^{66}$. Musi być uszlachetniona dobrym działaniem oraz świętością życia, gdyż bez nich staje się martwa ${ }^{67}$. Zatem można powiedzieć, iż wiara związana jest z uczynkami, a uczynki z wiarą.

Podsumowując poglądy Orygenesa, dotyczące dylematu pierwszych chrześcijan w kwestii relacji prawa wiary do Prawa uczynków, należy powiedzieć, iż opierają się one mocno na nauczaniu św. Pawła zawartym głównie w Liście do Rzymian. Apostoł Narodów podkreślał priorytet wiary nad Prawem Mojżeszowym. Scholarcha z Aleksandrii termin ,prawo" interpretuje szerzej. W sensie ścisłym bowiem Prawo jest niczym innym, jak „epinoią”

\footnotetext{
${ }^{62}$ Por. tamże III 10, PG 14, 957.

${ }^{63}$ Por. tamże II 7, PG 14, 887.

${ }^{64}$ Por. tamże I 13, PG 14, 858.

${ }^{65}$ Por. tamże III 11, PG 14, 957-958.

${ }^{66}$ Por. tenże, In Iesu Nave hom. 10, 3, ed. A. Jaubert, SCh 71, Paris 1960, 276.

${ }^{67}$ Por. tenże, Commentarium in Epistulam ad Romanos II 14, PG 14, 918.
} 
Syna Bożego, którego objawia zarówno Stary, jak i Nowy Testament. Stary Testament jest jednak tylko „figurą” i ,cieniem” prawd, zaś naukę w nim zawartą należy odczytać w świetle historiozbawczego procesu, którego centrum jest Jezus Chrystus i Jego objawienie w Nowym Testamencie. Literalnie interpretowane przepisy Prawa spełniły już swoją rolę w dziejach Narodu Wybranego. Przyjście Chrystusa i Jego dzieło sprawiły, że nakazy Prawa nabrały nowego znaczenia i należy je odczytywać alegorycznie, odnajdując ukrytą w nich treść duchową.

Zarówno prawo wiary, jak też Prawo Mojżeszowe, są nierozerwalnie związane z Prawem Bożym, którym winien się kierować człowiek dążący do osiągnięcia zbawienia. Jednak same uczynki Prawa nie przynoszą usprawiedliwienia przed Bogiem. Odpuszczenie grzechów i błogosławieństwo otrzymuje człowiek na podstawie wiary w Jezusa Chrystusa i mocą Jego łaski. Z wiary też, i przez wiarę, powstaje prawo, które obowiązuje wszystkich uczniów Chrystusa, a przejawia się w dobrych uczynkach: poście, miłosierdziu, pokucie. Jest ono darem Boga, a odwzorowaniem jego zasad są sprawiedliwość i świętość. Można więc stwierdzić, iż prawo wiary jest fundamentalne w życiu chrześcijanina. Wyraża się ono w przyjęciu prawa objawionego przez Chrystusa i jest rzeczywistością dynamiczną. Na wierze bowiem zasadzone jest poznanie, które prowadzi ostatecznie do Mądrości.

Niniejszy artykuł dotyczy jedynie niewielkiej, aczkolwiek ważnej i interesującej kwestii relacji wiary i uczynków, jednakże pozwala stwierdzić, iż w teologii Orygenesa daje się odczuć głęboką świadomość postępującego procesu recepcji objawienia oraz kształtowania się coraz wyraźniej znamion samoświadomości doktrynalnej Kościoła.

\author{
THE LAW OF FAITH OR THE DEEDS OF THE LAW? \\ THE DILEMMA OF THE FIRST CHRISTIANS \\ IN ORIGEN'S COMMENTARIUM IN EPISTULAM AD ROMANOS
}

\title{
(Summary)
}

One of the most crucial problems that split the newly developing Church was the argumentation between the baptized Jews, the Christians deriving from pagans and Gnostics mainly concerned the issue of respecting Moses Law and connected with it circumcision. That problem was deeply analyzed in the preaching of one of the most prominent Early-Christian writers and Church exegetes Origen (around $253 \mathrm{AD}$ ). Origen stressed that both the law of faith as well as Moses Law are strictly connected with God's Law, which every human should respect in order to reach salvation. And neither the deeds of natural law nor Moses Law have the justification power, since this is actually given directly from Christ via our faith and christening. So humans receive the remission of sins and blessing on the basis of faith, and it is the faith that contributes to salvation. Humans, who have been given salvation, are obliged to respect the law faith in their life, which concerns 
all Christ's disciples. And that should be manifested by fasting, mercy, penance, seeking wisdom, etc. We can state though that the law of faith, being God's gift, is fundamental in a Christian's life, and the reflection of that is justice and sainthood.

Key words: Origen, patristic theology, faith, the Law of Moses, the law of faith, Christian's life.

Słowa kluczowe: Orygenes, teologia patrystyczna, wiara, Prawo Mojżeszowe, prawo wiary, życie chrześcijańskie. 
